\title{
PEMODELAN SENYAWA TURUNAN ASAM KARBAMAT SEBAGAI SENYAWA ANTIKANKER MENGGUNAKAN METODE SEMIEMPIRIS AM1
}

\author{
Senny Widyaningsih, Purwati, Riyadi \\ Program Studi Kimia, Jurusan MIPA, Fakultas Sains dan Teknik, UNSOED, Purwokerto
}

\begin{abstract}
4- $\beta$ - $N$-carbamic acid-4'-dimetylpipodopylotoxin and its derivatives are compounds which are synthesized from etoposide (VP 16). These compounds are used as anticancer medicine because they inhibit DNA topoisomerase II enzyme. The enzyme participates in controlling breaking process of DNA double helix bounding in cancer cell. It makes cancer growing cease and dies because cell can not replicate. However, the compound insoluble in water, make a medicine resistant, inhibit metabolism system and poison. It needs to design a modification of new compounds from carbamic acid derivatives which have higher activity. Structure modification was done using Quantitative Structure Activity Relationship (QSAR) which was a computational chemistry application in medicine design process. This research used semiempiris AM1 method to determine the best QSAR equation based on multilinear regression analysize, with $\log 1 / \mathrm{IC}_{50}$ as dependent variable and independent variables were atomic net charge of $\mathrm{qN} 29, \mathrm{qC} 30$, qO31, qO32, dipole moment, n-octanol-water coefficient partition $(\log \mathrm{P})$, and polarity. The best QSAR equation in this research was : $\log 1 / \mathrm{IC}_{50}=4.871+12.738 \mathrm{qN} 29+$ $33.183 \mathrm{qC} 30+28.015 \mathrm{qO} 31-3.6 \times 10^{-2}$ polarity, with $\mathrm{N}=13, \mathrm{r}=0.907, \mathrm{SE}=0.13025$, $\mathrm{F}_{\text {count }} / \mathrm{F}_{\text {table }}=1.901$, PRESS $=0.1357$. Based on the best QSAR equation, the prediction compounds were $1,2,3,8$, and 22 with each $\mathrm{IC}_{50}$ theoretical value were $0.032,0.034$, 0.036 , and $0.098 \mu \mathrm{M}$.
\end{abstract}

Keywords : carbamic acid, QSAR, semiempiris AM1

\section{PENDAHULUAN}

Kanker adalah suatu penyakit akibat pertumbuhan sel yang tidak normal, yang tidak hanya terdapat pada manusia tetapi juga pada binatang dan tumbuh-tumbuhan. Kematian yang disebabkan oleh kanker menduduki urutan terbanyak kedua setelah penyakit kardiovaskuler, sedangkan di Indonesia angka kematian karena kanker menduduki urutan ke-6. Usaha pencarian obat antikanker dimulai tahun 1964-an dengan ditemukannya secara kebetulan nitrogen mustard yang dapat dipakai mengobati leukemia (Sukardja, 2000), berbagai usaha terus dilakukan diantaranya melalui isolasi senyawa hasil alam dan juga memodifikasikan senyawa tersebut dengan tujuan mendapatkan senyawa baru yang mempunyai aktivitas lebih tinggi.

Senyawa 4- $\beta$ - $N$-asam karbamat4'-dimetilpipodopilotoksin dan turunannya (Gambar 1) merupakan senyawa sintesis dari etoposide (VP16) yang banyak digunakan sebagai obat antikanker. Senyawa tersebut bekerja dengan menghambat enzim DNA topoisomerase II yang berperan dalam mengontrol proses pemecahan ikatan double helix DNA pada sel kanker sehingga perkembangan sel kanker terhenti dan mati karena tidak dapat melakukan proses replikasi sel (Duca, et al., 2005).

Meskipun senyawa $4-\beta-N$-asam karbamat-4'-dimetilpipodopilotoksin dan turunannya banyak digunakan dalam 
pengobatan kanker, namun memiliki beberapa kelemahan diantaranya kurang larut dalam air, memungkinkan terjadi resistensi obat, menghambat sistem metabolisme dan racun (Duca, et. al., 2005). Dampak negatif tersebut dapat dikurangi dengan melakukan desain senyawa baru turunan asam karbamat yang memiliki aktivitas lebih tinggi.

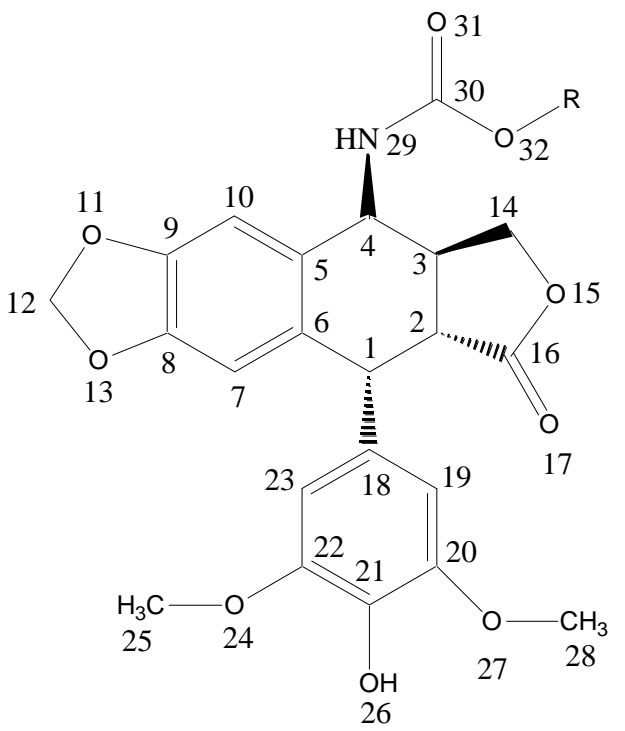

Gambar 1. Struktur senyawa 4- $\beta$ - $N$-asam karbamat 4'-dimetilpipodopilotoksin

Proses pencarian senyawa obat pada masa lampau melalui langkah eksperimen dengan biaya yang relatif besar, memerlukan waktu yang lama, dan adanya spekulasi (trial and error) namun hasil yang didapatkan seringkali senyawa produk tidak memiliki aktivitas yang lebih tinggi dari senyawa yang telah ada. Seiring dengan berkembangnya ilmu pengetahuan dan teknologi, tahun 1950 muncul kimia komputasi yang menjembatani antara kimia teori dengan eksperimen. Salah satu aplikasi kimia komputasi ialah Hubungan Kuantitatif Struktur dan Aktivitas (HKSA) yang dapat digunakan dalam proses desain obat secara teoritik yang kemudian hasilnya dapat dijadikan acuan dalam proses sintesis senyawa obat baru (Pranowo, 2002).
Metode semiempiris Austin Model 1 (AM1) dipilih untuk digunakan dalam penelitian ini karena cocok untuk sebagian besar senyawa organik, memiliki ketepatan prediksi yang lebih baik, tidak memerlukan memori yang besar dan waktu yang relatif cepat dalam proses perhitungannya (Tahir dan Wijaya, 2004). Metode kemometri yang digunakan dalam penelitian ini adalah metode statistik MLR (Multi Linear Regression) karena senyawa yang dikaji relatif banyak.

Pengujian model persamaan HKSA yang didapat pada desain obat perlu dilakukan untuk mengetahui keakuratannya, sehingga dibutuhkan data molekul fitting untuk mendapatkan model persamaan dan data molekul uji untuk pengujian akurasi model tersebut. Menurut Tahir dan Wijaya (2004) deskriptor yang berpengaruh terhadap aktivitas dapat dievaluasi dari model hubungan hasil pemisahan secara acak. Pengelompokan data dilakukan secara acak agar setiap data memiliki kesempatan untuk dipilih menjadi data fitting atau data uji.

Penelitian ini mencoba melakukan pemodelan matematis terbaik senyawa turunan asam karbamat sebagai senyawa antikanker menggunakan aplikasi kimia komputasi HKSA. Tahapan penelitian pemodelan senyawa turunan asam karbamat baru sebagai obat antikanker meliputi pemilihan deskriptor, perhitungan deskriptor, pemisahan data secara acak, analisis HKSA dan mendesain senyawa antikanker baru.

\section{METODE PENELITIAN}

Bahan yang digunakan dalam penelitian ini adalah data aktivitas antikanker senyawa 4- $\beta-N$-asam karbamat 4'-dimetilpipodopilotoksin dan turunannya berupa data kadar penghambat rata-rata $\left(\mathrm{IC}_{50}\right)$ eksperimen terhadap enzim topoisomerase II yang 
tersaji dalam Tabel 1, yang diperoleh dari literatur (Duca, et. al., 2005).

Tabel 1. Data hasil uji aktivitas sitotoksik senyawa turunan asam karbamat terhadap sel leukemia L1210

\begin{tabular}{|c|c|c|}
\hline $\mathbf{R}$ & $\begin{array}{c}\text { Inhibibisi } \\
\text { TI II }\end{array}$ & $\begin{array}{c}\mathbf{I C}_{50} / \\
\mu \mathbf{M}\end{array}$ \\
\hline $\mathrm{CH}_{3}$ & 50 & 0,18 \\
\hline $\mathrm{CH}_{2} \mathrm{CH}_{3}$ & 44 & 0,14 \\
\hline$\left(\mathrm{CH}_{2}\right)_{3} \mathrm{CH}_{3}$ & 40 & 0,23 \\
\hline$\left(\mathrm{CH}_{2}\right)_{3} \mathrm{Cl}$ & 31 & 0,15 \\
\hline $\mathrm{CH}_{2} \mathrm{CH}=\mathrm{CH}_{2}$ & 25 & 0,11 \\
\hline $\mathrm{CH}_{2} \mathrm{C} \equiv \mathrm{CH}$ & 29 & 0,09 \\
\hline$\left(\mathrm{CH}_{2}\right)_{2} \mathrm{OCH}_{3}$ & 42 & 0,14 \\
\hline & 10 & 0,14 \\
\hline$\left(\mathrm{CH}_{2}\right)_{2}-$ & 15 & 0,44 \\
\hline & 0,27 & 0,568 \\
\hline & 0,36 & 0,443 \\
\hline & 0,39 & 0,408 \\
\hline
\end{tabular}

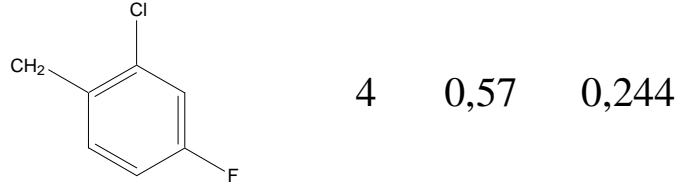

Ket : TI II = topoisomerase II

Peralatan yang digunakan pada penelitian ini adalah seperangkat komputer dengan spesifikasi :

a. Perangkat keras (hardware)

1) Processor tipe Pentium IV (intel ${ }^{\circledR}$ ) CPU 2,66GHz.

2) RAM $512 \mathrm{MB}$ dan hardisk $40 \mathrm{~GB}$

b. Perangkat lunak (software)

1) Program sistem operasi windows XP SP2

2) HyperChem versi 7.5 for windows (digunakan untuk optimasi geometri, menghitung struktur elektronik dan QSAR properties)

3) SPSS 14.0 for windows (untuk analisi statistik HKSA)

4) Microsoft Excel 2003 dari Microsoft, Inc.

\section{Pemilihan deskriptor}

Deskriptor merupakan variabel bebas yang mempengaruhi persamaan HKSA dan berfungsi untuk mengetahui variabel bebas yang mempengaruhi aktivitas antikanker. Pemilihan deskriptor merupakan langkah pertama yang penting dalam kajian HKSA. Jika hubungan antara deskriptor terpilih dan aktivitas kuat, selanjutnya aktivitas senyawa obat baru dapat diprediksi. Deskriptor yang digunakan dalam penelitian ini tersaji dalam Tabel 2. 
Molekul, Vol. 2. No. 2. Nopember, 2007 : 59- 70

Tabel 2. Deskriptor yang digunakan dan cara memprolehnya

\begin{tabular}{|c|c|c|c|c|}
\hline No. & Simbol & Deskriptor & Satuan & Cara Perhitungan \\
\hline 1. & $\mathrm{qC}_{4}$ & Muatan C No. 4 & Coloumb & $\begin{array}{l}\text { Semiempiris AM1, } \\
\text { HyperChem, } \\
\text { Optimasi struktur } \\
\text { senyawa }\end{array}$ \\
\hline 2. & $\mathrm{qN}_{29}$ & Muatan N No. 29 & Coloumb & $\begin{array}{l}\text { Semiempiris AM1, } \\
\text { HyperChem, } \\
\text { Optimasi struktur } \\
\text { senyawa }\end{array}$ \\
\hline 3. & $\mathrm{qC}_{30}$ & Muatan C No. 30 & Coloumb & $\begin{array}{l}\text { Semiempiris AM1, } \\
\text { HyperChem, } \\
\text { Optimasi struktur } \\
\text { senyawa }\end{array}$ \\
\hline 4. & $\mathrm{qO}_{31}$ & Muatan O No. 31 & Coloumb & $\begin{array}{l}\text { Semiempiris AM1, } \\
\text { HyperChem, } \\
\text { Optimasi struktur } \\
\text { senyawa }\end{array}$ \\
\hline 5. & $\mathrm{qO}_{32}$ & Muatan O No. 32 & Coloumb & $\begin{array}{l}\text { Semiempiris AM1, } \\
\text { HyperChem, } \\
\text { Optimasi struktur } \\
\text { senyawa }\end{array}$ \\
\hline 6. & $\mu$ & Momen dwi kutub & Debye & $\begin{array}{l}\text { Semiempiris AM1, } \\
\text { HyperChem, } \\
\text { Optimasi struktur } \\
\text { senyawa }\end{array}$ \\
\hline 7. & $\log P$ & $\begin{array}{l}\text { Koefisien partisi } \\
\text { n-oktanol-air }\end{array}$ & - & $\begin{array}{l}\text { QSAR properties, } \\
\text { HyperChem }\end{array}$ \\
\hline 8. & $\alpha$ & Polaritas & $\mathrm{A}^{3}$ & $\begin{array}{l}\text { QSAR properties, } \\
\text { HyperChem }\end{array}$ \\
\hline
\end{tabular}




\section{Perhitungan deskriptor dengan metode semiempiris AM1 dan QSAR properties}

Setiap senyawa 4- $\beta$ - $N$-asam

karbamat dari 4'-dimetilpipodopilotoksin dan turunannya dibuat struktur 2D dengan program HyperChem Release 7.5. Sebelum dilakukan perhitungan senyawa tersebut dianalisis sudut torsinya, selanjutnya perhitungan dilakukan dengan metode semiempiris AM1 dengan parameter seperti yang tersaji dalam Tabel 3. Setelah diperoleh struktur yang stabil, dilakukan pencatatan data perhitungan hasil geometri optimasi berupa file log (rekaman data) dengan perhitungan single point terhadap struktur tersebut. Deskriptor HKSA diperoleh dari QSAR properties, setelah senyawa dioptimasi kemudian dilakukan perhitungan QSAR properties dari menu compute pada HyperChem Realese 7.5.

Tabel 3. Parameter perhitungan metode semiempiris AM1

\begin{tabular}{lccclc}
\hline Metode & $\begin{array}{c}\text { Spin } \\
\text { pairing }\end{array}$ & $\begin{array}{c}\text { Batas } \\
\text { konvergensi } \\
\text { (SCF controls) }\end{array}$ & State & Algoritma & $\begin{array}{c}\text { RMS } \\
\text { gradients } \\
\text { (kkal/A.mol) }\end{array}$ \\
\hline $\begin{array}{l}\text { Semiempiris } \\
\text { AM1 }\end{array}$ & RHF & 0,001 & Lowest & $\begin{array}{l}\text { Polak- } \\
\text { Ribiere }\end{array}$ & 0,001 \\
\hline
\end{tabular}

Teknik pemisahan data secara acak

Teknik pemisahan senyawa menjadi dua kelompok yaitu data fitting dan data uji dilakukan berdasarkan nomor senyawa dengan teknik pemisahan acak pada perangkat lunak Microsoft Exel. Data awal yang digunakan sebanyak 13 yang diacak menggunakan fungsi RANDBETWEEN pada menu insert. Data yang diambil sebanyak 3 data dengan batasan antara 1 sampai 13 tanpa berulang. Tiga data yang pertama keluar merupakan data uji sedangkan 10 data sisanya merupakan data fitting.

\section{Analisis HKSA dengan SPSS}

a. Pemilihan deskriptor berpengaruh

Analisis penelitian HKSA ini menggunakan metode regresi multilinear dengan program SPSS for Windows versi 14 metode Backward. Variabel yang digunakan antara lain variabel tak bebas $\left(\log 1 / \mathrm{IC}_{50}\right)$ dan variabel bebas yang terdiri dari $\mathrm{qC}_{4}, \mathrm{qN}_{29}, \mathrm{qC}_{30}, \mathrm{qC}_{30}, \mathrm{qO}_{31}$, $\mathrm{qC}_{32}, \mu, \log \mathrm{P}$ dan kepolaran. Persamaan yang diperoleh diseleksi untuk mencari model yang terbaik dengan menggunakan parameter statistik r, $\mathrm{r}^{2}$, SE, nilai anova (F) dan PRESS.

\section{b. Pengujian model persamaan}

Pengujian keakuratan modelmodel persamaan yang diperoleh dapat dilakukan dengan menggunakan perhitungan PRESS terhadap data uji. Nilai PRESS dapat diperoleh dari persamaan:

$$
\text { PRESS }=\sum_{i=1}\left(Y_{\text {pred }}-Y_{o b s}\right)^{2}
$$

dengan $Y_{\text {pred }}$ adalah aktivitas prediksi senyawa asam karbamat dan turunannya, sedangkan $\mathrm{Y}_{\mathrm{obs}}$ adalah aktivitas eksperimen senyawa turunan asam karbamat. Nilai PRESS ini disebut PRESS $_{\text {eksternal. }}$ Model terpilih hasil uji ini digunakan untuk menunjukkan variabel bebas yang akan digunakan dalam persamaan HKSA akhir.

\section{c. Analisis persamaan HKSA akhir}

Variabel bebas yang terlibat pada model persamaan terbaik dari pengujian data senyawa fitting dan data senyawa uji digunakan untuk menentukan persamaan HKSA akhir dengan melakukan analisis regresi kembali terhadap 13 senyawa 
turunan asam karbamat menggunakan program SPSS dengan metode enter, sehingga diperoleh persamaan HKSA akhir.

\section{Desain senyawa antikanker baru turunan asam karbamat}

Berdasarkan persamaan HKSA terpilih, variabel bebas yang paling berpengaruh pada aktivitas antikanker dipilih untuk digunakan dalam desain struktur senyawa turunan asam karbamat yang baru secara teoritik dengan aktivitas antikanker yang lebih tinggi. Hasil desain ini dapat diusulkan untuk ditindaklanjuti pada proses sintesis senyawa baru.

\section{HASIL DAN PEMBAHASAN \\ Rekapitulasi Data Deskriptor Hasil Perhitungan AM1}

Hal pertama yang harus diperhatikan dalam pembuatan model struktur senyawa tiga dimensi ialah penomoran atom-atom yang menyusun senyawa asam karbamat dan turunannya agar memudahkan dalam menentukan muatan bersih masing-masing atom. Penomoran atom dalam penelitian ini dapat dilihat pada Gambar 2, kemudian dilakukan proses setup dengan memilih metode semiempiris AM1 dengan parameter seperti yang tercantum dalam Tabel 3. Model tiga dimensi dianalisis terlebih dahulu sudut torsinya melalui pilihan potential pada menu compute dengan tujuan diperoleh konformasi struktur senyawa 4 - $\beta$-N-asam karbamat-4'-dimetilpipodopilotoksin dan turunannya yang paling stabil. Analisis sudut torsi dilakukan pada dua bagian yakni bagian a dan b sebagaimana terlihat dalam Gambar 2.
Hasil Analisis sudut torsi pada bagian a diperoleh nilai sudut torsi yang stabil pada sudut $250^{\circ}$ dengan energi $5685,23 \mathrm{kkal} / \mathrm{mol}$ sedangkan bagian $\mathrm{b}$ pada sudut $270^{\circ}$ dengan energi $-5705,05$ $\mathrm{kkal} / \mathrm{mol}$. Hasil analisis sudut torsi ini digunakan untuk menentukan sudut torsi senyawa 4- $\beta$-N-asam karbamat-4'dimetilpipodopilotoksin dan turunannya yang akan dioptimasi dengan memasukkan nilai torsi tersebut melalui pilihan set bond torsion dari menu edit.

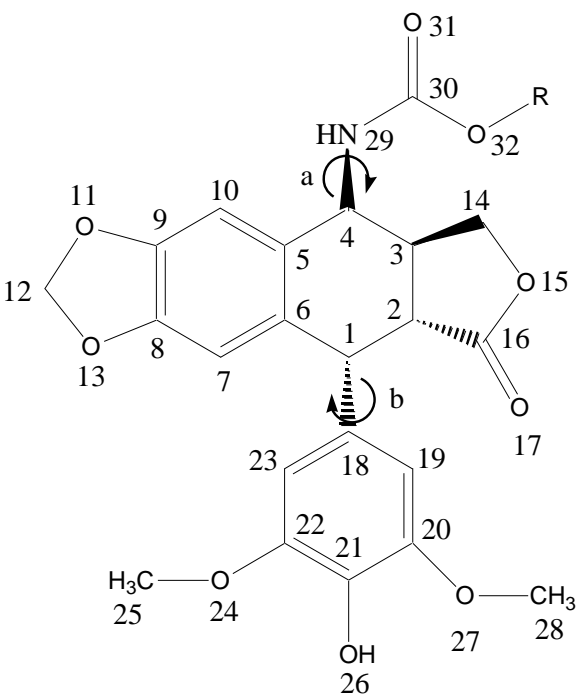

Gambar 2. Bagian senyawa asam karbamat dan turunannya yang dianalis sudut torsinya

Optimasi molekul dilakukan dengan memilih geometry optimization dari menu compute dengan parameter seperti yang tercantum dalam Tabel 3 . Optimasi berlangsung sampai diperoleh keadaan sistem yang seragam dengan meminimalisasi energi molekul sehingga diperoleh bentuk struktur yang paling stabil yang ditandai dengan convergensi $=$ yes. 
Permodelan senyawa....(Senny Widyaningsih dkk)

Tabel 4. Data hasil tabulasi deskriptor hasil perhitungan metode semiempiris AM1

\begin{tabular}{|c|c|c|c|c|c|c|c|c|c|}
\hline Senyawa & $\begin{array}{c}\log \\
1 / \mathrm{c} 50\end{array}$ & $\log P$ & $\begin{array}{c}\text { Dipol } \\
\text { (debye) }\end{array}$ & $\begin{array}{c}\text { Polaritas } \\
0^{0} \\
\mathrm{~A}^{3}\end{array}$ & $\begin{array}{c}\mathbf{q C}_{4} \\
\text { (Coulomb) }\end{array}$ & $\begin{array}{c}\mathbf{q N}_{29} \\
\text { (Coulomb) }\end{array}$ & $\begin{array}{c}\mathrm{qc}_{30} \\
\text { (Coulomb) }\end{array}$ & $\underset{\text { (Coulomb) }}{\mathbf{q O}_{31}}$ & $\underset{(\mathrm{Coulomb})}{\mathbf{q O}_{32}}$ \\
\hline 1 & 0,745 & $-3,713$ & 2,844 & 43,939 & 0,083 & $-0,334$ & 0,381 & $-0,384$ & $-0,284$ \\
\hline 2 & 0,854 & $-3,371$ & 3,011 & 45,774 & 0,083 & $-0,336$ & 0,384 & $-0,387$ & $-0,288$ \\
\hline 3 & 0,638 & $-2,506$ & 2,994 & 49,444 & 0,083 & $-0,336$ & 0,384 & $-0,387$ & $-0,287$ \\
\hline 4 & 0,824 & $-2,957$ & 4,045 & 49,537 & 0,085 & $-0,336$ & 0,386 & $-0,383$ & $-0,293$ \\
\hline 5 & 0,959 & $-2,972$ & 2,968 & 47,417 & 0,084 & $-0,336$ & 0,387 & $-0,387$ & $-0,286$ \\
\hline 6 & 1,046 & $-3,439$ & 2,915 & 46,505 & 0,082 & $-0,334$ & 0,386 & $-0,388$ & $-0,280$ \\
\hline 7 & 0,854 & $-3,878$ & 4,177 & 48,246 & 0,084 & $-0,337$ & 0,388 & $-0,387$ & $-0,285$ \\
\hline 8 & 0,854 & $-3,085$ & 3,843 & 52,977 & 0,084 & $-0,338$ & 0,382 & $-0,382$ & $-0,283$ \\
\hline 9 & 0,357 & $-4,719$ & 4,883 & 53,863 & 0,094 & $-0,346$ & 0,393 & $-0,400$ & $-0,277$ \\
\hline 10 & 0,569 & $-2,700$ & 3,181 & 53,599 & 0,085 & $-0,339$ & 0,388 & $-0,384$ & $-0,283$ \\
\hline 11 & 0,444 & $-3,301$ & 1,959 & 53,508 & 0,084 & $-0,336$ & 0,389 & $-0,396$ & $-0,280$ \\
\hline 12 & 0,409 & $-3,049$ & 1,408 & 55,343 & 0,084 & $-0,336$ & 0,383 & $-0,388$ & $-0,289$ \\
\hline 13 & 0,244 & $-3,145$ & 1,904 & 57,455 & 0,084 & $-0,335$ & 0,388 & $-0,398$ & $-0,273$ \\
\hline
\end{tabular}

Nilai momen dwikutub

Berdasarkan data muatan bersih atomatom senyawa 4- $\beta$-N-asam karbamat-4'dimetilpipodopilotoksin dan turunannya perhitungan terlihat bahwa atom yang terikat dengan gugus $\mathrm{R}$ memiliki nilai muatan yang berbeda dengan muatan atom lainnya. Hal ini terjadi karena adanya pengaruh dari gugus subtitusi $\mathrm{R}$, perbedaan subtituen mempengaruhi bertambah dan berkurangnya nilai muatan atom karena adanya pengaruh induksi dari gugus subtituen tersebut. Perbedaan paling besar terjadi pada atom O nomor 32 karena merupakan tempat menempel langsung subtituen diikuti atom $\mathrm{qO}_{31}, \mathrm{qN}_{29}, \mathrm{qC} 4$, dan $\mathrm{qC}_{30}$. dipengaruhi oleh muatan bersih atomatom dalam suatu senyawa, nilai paling tinggi sebesar 4,883 Debye dimiliki oleh senyawa nomor 9 karena memiliki banyak atom bebas dari $\mathrm{N}$ dan $\mathrm{O}$ sehingga momen dwikutubnya tinggi. Senyawa nomor 7 momen dwikutubnya relatif tinggi 4,177 Debye karena gugus subtituennya mengandung atom $\mathrm{O}$ yang memiliki keelektronegatifan yang besar akibatnya perbedaan distribusi muatan tidak merata yang berpengaruh pada nilai momen dwikutub. Senyawa nomor 4 memiliki momen dwikutub yang tinggi pula sebesar 4,045 karena terdapat gugus $\mathrm{Cl}$ yang memiliki keelektronegatifan besar sehingga momen dwikutubnya besar pula. 
Nilai $\log \mathrm{P}$ (Koefisien partisi $n$ oktanol/air) menunjukkan kelarutan senyawa tersebut diantara larutan nonpolar dan polar. Salah satu faktor yang mempengaruhi nilai $\log \mathrm{P}$ adalah panjang rantai C. Semakin panjang rantai $\mathrm{C}$ maka semakin nonpolar larutan tersebut. Nilai $\mathrm{P}$ yang besar menunjukkan bahwa senyawa lebih larut dalam keadaan nonpolar (lipid) daripada polar (air), nilai $\log \mathrm{P}$ paling tinggi dimiliki oleh senyawa nomor 3 sebesar 2,506.

Polaritas dipengaruhi oleh keelektronegatifan atom-atom penyusun molekul, semakin besar perbedaan keelektronegatifan maka semakin polar senyawanya. Hasil penelitian diketahui nilai polaritas yang tinggi dimiliki oleh senyawa nomor 13 sebesar 57,455 dan yang paling kecil senyawa nomor 1 sebesar 43,393. Senyawa nomor 13 subtituennya memiliki atom yang mempunyai keelektronegatifan yang besar yakni atom $\mathrm{F}$ dan $\mathrm{Cl}$ sehingga kepolarannya besar, sebaliknya senyawa nomor 1 tidak memiliki atom yang memiliki nilai keelektronegatifan yang tinggi pada gugus subtituennya sehingga nilai polaritasnya kecil.

\section{Hasil Pemisahan Data Secara Acak}

Pemisahan data dilakukan untuk membuat data fitting dan data uji dari senyawa 4- $\beta$-N-asam karbamat-4'dimetilpipodopilotoksin dan turunannya, data fitting digunakan untuk membuat model-model persamaan, sedangkan data uji berfungsi untuk menguji keakuratan masing-masing model persamaan. Pemisahan data dilakukan secara acak dengan tujuan memberikan kesempatan yang sama kepada setiap senyawa untuk dipilih menjadi data fitting atau data uji. Hasil pemisahan diperoleh senyawa no. 1, 2, dan 3 masuk dalam senyawa uji, sedangkan sisanya termasuk senyawa fitting.

\section{Perhitungan Analisis Statistik Multi Linear Regression (MLR)}

Perhitungan statistik Multi Linear Regression (MLR) dilakukan dengan menggunakan metode Backward terhadap sepuluh senyawa data fitting. Variabel bebas diisi dengan data deskriptor $\mathrm{qC}_{4}$, $\mathrm{qN}_{29}, \mathrm{qC}_{30}, \mathrm{qO}_{31}, \mathrm{qO}_{32}, \log \mathrm{P}$, momen dipol dan polaritas, sedangkan data aktivitas $\log 1 / \mathrm{IC}_{50}$ digunakan sebagai variabel tak bebas. Metode Backward bekerja pertama-tama dengan memasukkan semua variabel bebas, kemudian membuang satu demi satu variabel bebas yang tidak berpengaruh pada perhitungan Multi Linear Regression (MLR), variabel-variabel yang dikeluarkan tidak selalu berpengaruh melainkan seringkali sudah diwakili oleh variabel lainnya. Hasil perhitungan SPSS analisis statistik Multi Linear Regression (MLR) metode Backward terdapat dalam Tabel 5.

Tabel 5. Model persamaan HKSA terpilih hasil analisis Multi Linear Regression (MLR) metode Backward

\begin{tabular}{|c|c|c|c|c|c|}
\hline Model & Variabel & $\mathbf{r}$ & $\mathbf{r}^{2}$ & SE & $\begin{array}{l}\mathbf{F}_{\text {hitung }} \\
/ \mathbf{F}_{\text {tabel }}\end{array}$ \\
\hline 1 & $\begin{array}{l}\mathrm{qC}_{4}, \mathrm{qN}_{29}, \mathrm{qC}_{30}, \mathrm{qO}_{31}, \mathrm{qO}_{32}, \mu, \log \\
\mathrm{P}, \text { polaritas }\end{array}$ & 0,915 & 0,993 & 0,06743967 & 0,077 \\
\hline 2 & $\begin{array}{l}\mathrm{qC}_{4}, \mathrm{qN}_{29}, \mathrm{qC}_{30}, \mathrm{qO}_{31}, \mu, \log \mathrm{P}, \\
\text { polaritas }\end{array}$ & 0,996 & 0,993 & 0,04978898 & 1,994 \\
\hline 3 & $\mathrm{qC}_{4}, \mathrm{qN}_{29}, \mathrm{qC}_{30}, \mathrm{qO}_{31}, \mu$, olaritas & 0,995 & 0,990 & 0,04746094 & 5,527 \\
\hline 4 & $\mathrm{qN}_{29}, \mathrm{qC}_{30}, \mathrm{qO}_{1}, \mu$, polaritas & 0,991 & 0,983 & 0,05378034 & 7,328 \\
\hline 5 & $\mathrm{qN}_{29}, \mathrm{qC}_{30}, \mathrm{qO}_{31}$, polaritas & 0,986 & 0,972 & 0,06169020 & 8,294 \\
\hline
\end{tabular}


Uji Statistik Model Persamaan HKSA

Uji statistik yang pertama dilakukan terhadap nilai korelasi (r) yang menunjukkan hubungan antara variabel bebas dengan variabel tidak bebas dalam model persamaan HKSA yang diperoleh, nilai $r$ berada antara 0-1. Semakin mendekati 1 nilai $r$ maka persamaan tersebut memiliki hubungan yang tinggi antara variabel bebas dan variabel tak bebasnya. Nilai $r$ tertinggi diperoleh model persamaan 1 sebesar 0,997 dan terkecil persamaan 5 sebesar 0,986 . Uji statistik selanjutnya dilakukan terhadap nilai koefisien determinan $\left(\mathrm{r}^{2}\right)$ yang menjelaskan berapa \% aktivitas biologis yang dapat dijelaskan hubungannya dengan parameter sifat kimia fisik yang digunakan. Persamaan 1 dengan nilai $\mathrm{r}^{2}$ tertinggi dapat menjelaskan $99 \%$ dari variasi antar data sedangkan persamaan 5 dengan nilai $\mathrm{r}^{2}$ terkecil dapat menjelaskan 97\% hubungan parameter sifat kimia fisik yang digunakan dengan aktivitasnya. Standar Errors (SE) merupakan parameter uji statistik berikutnya, yang menjelaskan tingkat kesalahan persamaan HKSA yang diperoleh. Semakin kecil nilai SE maka model persamaan regresi tersebut semakin baik. Nilai SE terkecil dimiliki oleh model persamaan 3, 2, 4, dan 5, dan nilai SE tertinggi dimiliki oleh model 1.

Nilai Anova (F) berfungsi untuk melihat pengaruh secara keseluruhan variabel bebas terhadap variabel tak bebas, digunakan untuk menguji apakah persamaan yang didapatkan ada hubungan linearitasnya atau hanya sebuah kebetulan. Persamaan HKSA dianalisis dengan membandingkan nilai $F_{\text {hitung dengan }} F_{\text {tabel. }}$. Jika $F_{\text {hitung }}>F_{\text {tabel }}$ atau nilai $F_{\text {hitung }} / F_{\text {tabel }}>1$ maka persamaan tersebut ada hubungan linearitas bukan hanya sebuah kebetulan semata. Semakin besar nilai $F_{\text {hitung }} / F_{\text {tabel }}$ maka semakin signifikan persamaan tersebut. Nilai Anova tertinggi dimiliki oleh model 5 sebesar 8,294.

Penggunaan keempat parameter $r$, $r^{2}$, SE dan $F$ secara statistik telah mencukupi untuk memilih model persamaan terbaik tetapi belum dapat memberikan gambaran yang nyata tentang kemampuan prediksi dari masing-masing model persamaan yang diperoleh hasil perhitungan statistik Multi Linear Regression (MLR). Prediction Residual Sum of Squares (PRESS) digunakan sebagai parameter uji selanjutnya untuk mengetahui kemampuan prediksi model-model persamaan tersebut, menurut Draper dan Smith (1981) semakin kecil nilai PRESS suatu model persamaan HKSA maka kemampuannya untuk memprediksi aktivitas biologi semakin baik. Nilai PRESS diperoleh dengan memasukkan variabel-variabel yang berpengaruh terhadap model-model persamaan hasil perhitungan Multi Linear Regression (MLR) metode backward terhadap data uji hasil pemisahan secara acak. Nilai PRESS terkecil dimiliki oleh model persamaan no. 5 sebesar 0,20452 seperti pada Tabel 6.

Tabel 6. Hasil perhitungan PRESS terhadap model-model HKSA metode backward menggunakan Microsoft Excel 2003

\begin{tabular}{|c|c|c|c|c|c|c|}
\hline \multirow[b]{2}{*}{ Senyawa } & \multirow[b]{2}{*}{$\begin{array}{c}\log 1 / \mathbf{I C}_{50} \\
\text { eksp }\end{array}$} & \multicolumn{5}{|c|}{ Residual } \\
\hline & & $\begin{array}{c}\text { model } \\
1\end{array}$ & $\begin{array}{c}\text { model } \\
2\end{array}$ & $\begin{array}{c}\text { model } \\
3\end{array}$ & $\begin{array}{c}\text { model } \\
4\end{array}$ & $\begin{array}{c}\text { model } \\
5\end{array}$ \\
\hline 1 & 0,74473 & 0,11932 & 0,07622 & 0,06417 & 0,04080 & 0,04874 \\
\hline 8 & 0,85387 & 0,15720 & 0,23329 & 0,25311 & 0,23720 & 0,14659 \\
\hline 11 & 0,4437 & 0,01187 & 0,02047 & 0,02352 & 0,02317 & 0,00919 \\
\hline & PRESS & 0,28840 & 0,32999 & 0,34080 & 0,30118 & 0,20452 \\
\hline
\end{tabular}




\section{Penentuan Model Persamaan HKSA Terbaik}

Berdasarkan uji parameterparameter statistik yang telah dilakukan terhadap kelima model persamaan HKSA hasil perhitungan statistik Multi Linear Regression (MLR) metode Backward, maka model no. 5 dipilih sebagai model HKSA terbaik. Model no 5 memiliki nilai PRESS terkecil 0,20452, nilai anova $\mathrm{F}$ tertinggi 8,294 dan selisih antara $r, r^{2}$ dan SE yang relatif kecil sebesar $0,01,0,03$, dan 0,02. Model persamaan HKSA nomor 5 sebagai model persamaan terbaik adalah sebagai berikut :

$\log 1 / \mathrm{IC}_{50}=3,552+27,274 \mathrm{qN} 29+$ $38,769 \mathrm{qC} 30+15,386 \mathrm{qO} 31-$

$5,2910^{-2}$ polaritas

$\mathrm{N}=10$

$\mathrm{r}=0,986$

$\mathrm{SE}=0,0616$

Fhitung/Ftabel $=8,294$

PRESS $=0,20452$

\section{Penentuan Persamaan HKSA Akhir}

Persamaan HKSA terbaik hasil metode backward selanjutnya digunakan untuk mencari model persamaan akhir HKSA yang akan digunakan dalam desain senyawa obat baru. Penentuan persamaan akhir HKSA diperoleh dengan memasukan variabel-variabel yang terlibat dalam model persamaan terbaik (model no. 5) terhadap seluruh data hasil perhitungan komputasi metoda AM1 dengan menggunakan perhitungan statistik Multi Linear Regression (MLR) metode enter. Hasil perhitungan metode enter diperoleh persamaan akhir HKSA sebagai berikut :

$\log 1 / \mathrm{IC}_{50}=4,871+12,738 \mathrm{qN} 29+$ $33,183 \mathrm{qC} 30+28,015 \mathrm{qO} 31$

$-3,6 \times 10^{-2}$ polaritas

$\mathrm{N}=13$

$\mathrm{r}=0,907$

$\mathrm{SE}=0,13025$

$\mathrm{F}_{\text {hitung }} / \mathrm{F}_{\text {tabel }}=1,901$

PRESS $=0,1357$

\section{Strategi Desain Senyawa Baru}

Berdasarkan persamaan HKSA akhir dilakukan proses modifikasi struktur senyawa $4-\beta$ - $\mathrm{N}$-asam karbamat4'-dimetilpipodopilotoksin dan turunannya pada bagian gugus subtituten $\mathrm{R}$ dengan memperhatikan deskriptordeskriptor yang mempengaruhi persamaan HKSA yakni muatan atom $\mathrm{N}_{29}, \mathrm{C}_{30}, \mathrm{O}_{31}$, dan polaritas. Proses modifikasi struktur dilakukan dengan menggunakan pendekatan metode Topliss dengan memasukan gugus-gugus yang mempunyai sifat lipofilik, elektronik dan sterik pada posisi tertentu struktur senyawa penuntun (Siswandono dan Soekardjo, 1998).

Hasil modifikasi struktur asam karbamat dan turunannya diperoleh lima senyawa prediksi terbaik dengan nilai teoritik $\mathrm{IC}_{50}$ sebesar 0,032, 0,034, 0,036, 0,059, dan 0,098 $\mu \mathrm{g} / \mathrm{mL}$ (Gambar 3) dari 30 senyawa yang dimodifikasi. 


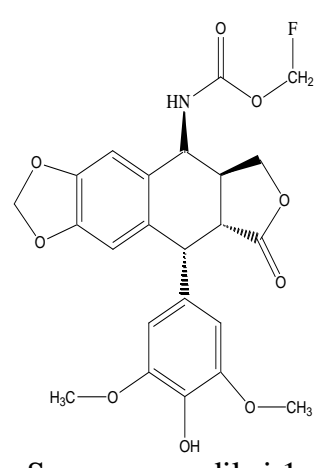

Senyawa prediksi 1

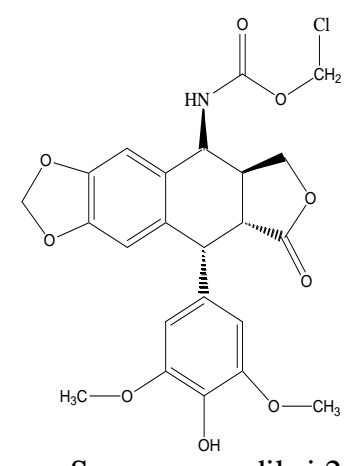

Senyawa prediksi 2

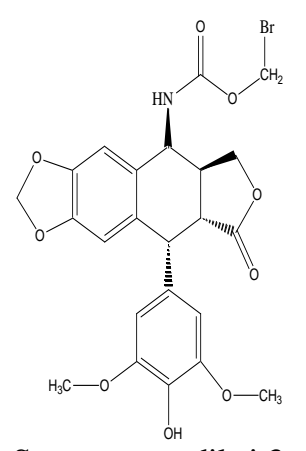

Senyawa prediksi 3

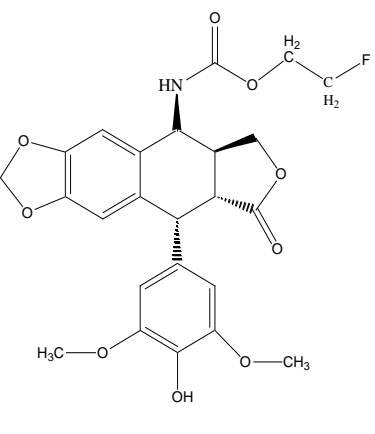

Senyawa prediksi 4

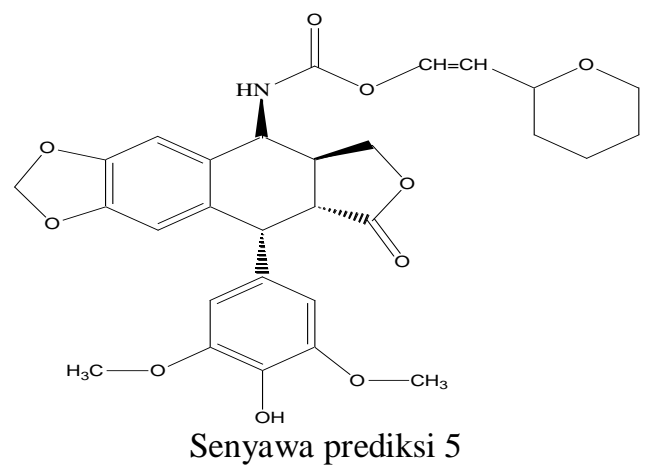

Gambar 3. Struktur molekul senyawa prediksi terbaik

\section{DAFTAR PUSTAKA}

Draper, D.K. dan Smith. 1981. Analisis Regresi Terapan. Terjemahan oleh Bambang Sumantri. 1992. Gramedia. Jakarta.

Duca, M., P. B. Arimondo, S. Leonce, A. Pierre, B. Pfeiffer, C. Monneret, and D. Dauzonne. 2005. NovelCarbamate derivaties of 4-

\section{KESIMPULAN}

1. Struktur senyawa turunan asam karbamat hasil perhitungan AM1 mempunyai hubungan yang berarti dengan aktivitas antikanker senyawa turunan asam karbamat.

2. Model persamaan HKSA terbaik yang menghubungkan struktur turunan asam karbamat dengan aktivitasnya sebagai obat antikanker adalah :

$\log 1 / \mathrm{IC}_{50}=4,871+12,738 \mathrm{qN} 29+$ $33,183 \mathrm{qC} 30+28,015 \mathrm{qO} 31$

$$
\begin{gathered}
-3,6 \times 10^{-2} \text { polaritas } \\
\mathrm{N}=13 \quad \mathrm{r}=0,907 \quad \mathrm{SE}=0,13025 \\
\mathrm{~F}_{\text {hitung }} / \mathrm{F}_{\text {tabel }}=1,901 \quad \text { PRESS }=0,1357
\end{gathered}
$$

3. Senyawa prediksi turunan asam karbamat baru hasil modifikasi dengan menggunakan persamaan HKSA terbaik yang memiliki aktivitas teoritik yang lebih tinggi dibandingkan senyawa turunan asam karbamat yang telah ada yaitu senyawa prediksi 1, 2, 3, 8, dan 22 .

$\beta$-amino-4'O-demethyl-4-

desoxypodo[hyllotoxin as inhibitors of topoisomerase II: synthesis and biological evaluation. (on-line). http://www.rsc.org/obc.

Pranowo, H. D. 2002. Kimia Komputasi. Pusat Kimia Komputasi Indonesia-Austria Kimia FMIPA UGM. Yogyakarta. 
Siswandono dan B. Soekardjo. 1998. Prinsip-prinsip Rancangan Obat. Cetakkan Pertama. Airlangga University Press. Surabaya.

Sukardja, I D. G. 2000. Onkologi Klinik. Edisi 2. Airlangga University Press. Surabaya.
Tahir, I., dan K. Wijaya. 2004. "Aplikasi Pemisahan Data Secara Acak pada Analisis Hubungan Kuantitatif Struktur Elektronik dan Aktivitas Senyawa Indolialkilamina". Seminar Nasional Hasil Penelitian Farmasi 2004. 190-200. 